\title{
PENGARUH KONSENTRASI SUKROSA TERHADAP KARAKTERISTIK SARI BUAH PROBIOTIK TERONG BELANDA (Solanum betaceaum Cav.) TERFERMENTASI DENGAN ISOLAT Lactobacillus sp. F213
}

\author{
The Effect of Sucrose Concentration on The Characteristics of Tamarillo (Solanum betaceaum \\ Cav.) Probiotic Juice Fermented by Lactobacillus sp. F213 \\ ${ }^{1}$ Ida Ayu Agung Prawitasari, ${ }^{2}$ Komang Ayu Nocianitri*, ${ }^{2}$ I Nengah Kencana Putra \\ ${ }^{1}$ Mahasiswa Program Studi Ilmu dan Teknologi Pangan, Fakultas Teknologi Pertanian, Unud \\ ${ }^{2}$ Dosen Program Studi Ilmu dan Teknologi Pangan, Fakultas Teknologi Pertanian, Unud \\ Kampus Bukit Jimbaran, Badung-Bali
}

\begin{abstract}
This research was aimed to determine the effect of sucrose on the characteristics of tamarillo probiotic juice which was fermented by Lactobacillus sp. F213 and to determine the concentration of sucrose that produced the best characteristic of fermented tamarillo probiotic juice. This research used random block design with concentration of sucrose as treatments, which consisted of five levels: $0 \%, 3 \%, 6 \%, 9 \%$, and $12 \%$. Treatment was repeated 3 times to obtain 15 units of sample. Data were analyzed by analysis of variance followed by multiple comparison test of Duncan Multiple Range Test (DMRT). The result showed that different concentration of sucrose significantly affected total lactic acid bacteria (LAB), total sugar, total acid, $\mathrm{pH}$, color (score), flavor (hedonic), sour taste (score), sweet taste (score), overall acceptance (hedonic), but had no significant effect on color (hedonic) and aroma (hedonic). The 9\% sucrose treatment produced the best fermented tamarillo probiotic juice with the characteristics of $9.31 \log \mathrm{CFU} / \mathrm{mL}$ total $\mathrm{LAB}, 16.98 \%$ total sugar, $1.53 \%$ total acid, $\mathrm{pH}$ of 4,31, orange color, with slightly sour and sweet taste, aroma, and overall acceptance liked slightly.
\end{abstract}

Keywords: tamarillo juice, probiotic, sucrose, Lactobacillus sp.

\section{PENDAHULUAN}

Dewasa ini masyarakat menyadari pentingnya mengkonsumsi pangan fungsional. Minuman probiotik merupakan salah satu jenis produk pangan fungsional. Minuman probiotik yang beredar di masyarakat sebagian besar merupakan produk fermentasi susu antara lain yogurt, kefir, koumiss, bulgarican milk, yakult. Disamping itu terdapat berbagai jenis buah yang dapat diolah menjadi minuman probiotik. Sari buah memiliki potensi untuk dikembangkan menjadi minuman probiotik hal ini didukung oleh pernyataan Ding dan Shah (2008) bahwa sari buah mengandung kadar gula, vitamin dan mineral tinggi yang dimanfaatkan oleh perkembangan bakteri probiotik. Pemanfaatan buah selain sebagai diversifikasi pangan juga

*Korespondensi Penulis:

E-mail: nocianitri@unud.ac.id dapat meningkatkan umur simpan dan nilai ekonomis buah.

Probiotik adalah mikroba hidup pada pangan apabila dikonsumsi dalam jumlah yang sesuai dapat memberikan manfaat bagi kesehatan inangnya (FAO/WHO, 2001). Bakteri asam laktat (BAL) yang dapat berperan dalam pembuatan minuman probiotik salah satunya adalah Lactobacillus sp. F213 (LbF213). LbF213 sebagai isolat minuman probiotik memiliki karakteristik, yaitu tahan terhadap $\mathrm{pH}$ rendah, enzim pencernaan dan asam empedu, memiliki kemampuan melekat pada epitel saluran pencernaan mencit untuk mencegah diare dan stimulasi sistem imun (Sujaya et al., 2012).

Terong belanda merupakan salah satu jenis buah termasuk dalam family Solanaceae yang dapat dimanfaatkan sebagai bahan dasar minuman probiotik. Buah terong belanda 
memiliki rasa seperti tomat dengan kandungan gizi diantaranya yaitu 10,3\% karbohidrat, $2 \%$ protein, $0,6 \%$ lemak, vitamin $\mathrm{A}, \mathrm{B}, \mathrm{C}, \mathrm{E}$, serat, kalsium, serta senyawa $\beta$-karoten, antosianin, flavonol, asam fenolik (Djufry et al.,2016). Pemanfaatan buah terong belanda sebagai bahan dasar minuman probiotik terfermentasi didukung oleh pernyataan Rini, 2019 yaitu viabilitas LbF213 pada sari buah terong belanda menunjukkan stabilitas yang baik selama 12 hari penyimpanan pada suhu $4^{\circ} \mathrm{C}$. Karbohidrat, protein, lemak, vitamin dan mineral dalam buah terong belanda dimanfaatkan untuk pertumbuhan bakteri sehingga diharapkan dapat mempertahankan viabilitas LbF213 dalam minuman probiotik.

Kualitas minuman probiotik terfermentasi dipengaruhi oleh beberapa faktor seperti suhu inkubasi, waktu fermentasi, ketersediaan nutrisi, konsentrasi starter, konsentrasi sari buah, dan lain sebagainya. Penambahan sukrosa selain sebagai sumber nutrisi pertumbuhan BAL juga berfungsi sebagai pemberi cita rasa manis. Penambahan sukrosa tergantung pada jenis buah yang digunakan. Karakteristik terbaik minuman probiotik jambu biji diperoleh dengan penambahan konsentrasi sukrosa 4\% (Nurainy et al., 2018). Menurut Seelam et al., 2017 konsentrasi sukrosa yang optimal untuk pembuatan minuman probiotik tomat adalah $10 \%$.

Konsentrasi sukrosa yang sesuai diduga dapat memberikan kondisi optimal bagi pertumbuhan BAL. Menurut Yunus dan Zubaidah, 2015, semakin banyak sukrosa maka semakin banyak substrat yang dapat dirombak oleh BAL menjadi asam laktat dan asam organik lainnya yang menimbulkan flavor khas, namun jika penambahan sukrosa melebihi batas optimal akan menyebabkan semakin banyak air yang keluar dari dalam sel bakteri, sehingga sel bakteri kekurangan air dan mati karena terjadi plasmolisis (Membre et al.,1999). Penambahan sukrosa $15 \%$ pada yoghurt susu kulit pisang kapok dan kacang hijau dapat menghambat pertumbuhan BAL (Dante et al.,2016), sebaliknya, jika tidak tersedia sukrosa sebagai substrat fermentasi diduga pertumbuhan BAL kurang optimal dan flavor asam dalam minuman probiotik tidak dapat tertutupi, oleh karena itu diperlukan penelitian mengenai pengaruh konsentrasi sukrosa dan penentuan konsetrasi sukrosa yang sesuai untuk memperoleh sari buah probiotik terong belanda terfermentasi dengan karakteristik terbaik.

\section{METODE PENELITIAN Tempat dan Waktu}

Penelitian ini dilaksanakan di UPT. Laboratorium Biosain dan Bioteknologi Universitas Udayana, Laboratorium Biokimia dan Nutrisi, Laboratorium Rekayasa Proses dan Pengendalian Mutu Fakultas Teknologi Pertanian, Bukit Jimbaran, Jl. Raya Kampus Udayana, Bukit Jimbaran. Pelaksanaan penelitian ini dilakukan pada bulan Juni hingga Agustus 2019.

\section{Bahan dan Alat}

Alat yang digunakan adalah botol kaca, juicer extractor, baskom, tabung reaksi (pyrex), jarum ose, inkubator, laminar air flow, spektrofotometer (evolution 201), $\mathrm{pH}$ meter (martini instrument, USA), timbangan analitik (Shimadzu AUX220, Japan), mikroskop (Olympus CX21FS1,Jerman), pipet mikro (Finnipipette), pipet volume, labu ukur, erlenmeyer (pyrex), kertas saring, autoklaf, magnetik stirer, waterbath (nvc thermologic)dan bunsen, blender, tip $100 \mu \mathrm{L}$, vortex, gelas objek, freezer, pisau, talenan, microtube, sentrifugasi, gelas ukur, batang bengkok, kulkas, dan labu ukur.

Bahan yang digunakan dalam penelitian ini adalah isolat LbF213 (koleksi UPT Biosain dan Bioteknologi Universitas Udayana), buah terong belanda (diperoleh di Pasar Kidul, Bangli), air mineral aqua, sukrosa, alkohol 96\%, MRS Agar 
(Oxoid,Inggris), MRS Broth (Oxoid,Inggris), aquades, $\mathrm{NaCl} 0,85 \%$, gliserol, kristal violet, larutan lugol, pewarna safranin, pereaksi anthrone, $\mathrm{H}_{2} \mathrm{SO}_{4}$ pekat, phenolphtalein $1 \%$, glukosa standar, larutan buffer $\mathrm{pH} 4$ dan 7 , larutan $\mathrm{H}_{2} \mathrm{O}_{2}$, indikator $\mathrm{PP}, \mathrm{NaOH} 0,1 \mathrm{~N}, \mathrm{HCl}$ $4 \mathrm{~N}$, alumunium foil dan tisu.

\section{Rancangan Percobaan}

Rancangan percobaan yang digunakan pada penelitian ini adalah Rancangan Acak Kelompok (RAK) dengan perlakuan konsentrasi sukrosa yaitu, S0 (Konsentrasi sukrosa 0\% ), S1 (Konsentrasi sukrosa 3\%), S2 (Konsentrasi sukrosa 6\% ), S3 (Konsentrasi sukrosa 9\%), S4 (Konsentrasi sukrosa 12\%). Masing-masing perlakuan diulang sebanyak 3 kali sehingga diperoleh 15 unit percobaan. Data yang diperoleh kemudian dianalisis dengan sidik ragam dan apabila terdapat pengaruh antara perlakuan dilanjutkan dengan Uji Duncan (Gomez dan Gomez, 1995).

\section{Pelaksanaan Penelitian \\ Penyegaran dan Uji Konfirmasi Isolat}

Penyegaran bakteri dilakukan dengan cara diambil $100 \mu \mathrm{L}$ stok isolat yang disimpan dalam gliserol $30 \%$, suhu $-20^{\circ} \mathrm{C}$ dan diinokulasi pada $5 \mathrm{~mL}$ media MRS Broth dan diinkubasi selama 24 jam dengan suhu $37^{\circ} \mathrm{C}$. Hasil positif ditunjukkan dengan munculnya kekeruhan pada media. Setelah penyegaran, dilakukan konfirmasi isolat melalui uji katalase, pewarnaan gram, dan uji gas (Suryani et al., 2010).

\section{Pembuatan Sari Buah Terong Belanda}

Pembuatan sari buah terong belanda diawali dengan proses sortasi. Buah yang digunakan adalah buah yang telah masak. Buah dicuci dan dipotong secara vertikal menjadi 2 bagian kemudian dipisahkan dari kulitnya. Buah dihancurkan dengan juicer kemudian ditambah air dengan perbandingan air dan buah (1:2), selanjutnya disaring dengan kain saring, sehingga dihasilkan sari buah tanpa ampas.

\section{Pembuatan Starter Sari Buah Terong Belanda}

Tahap awal yang dilakukan adalah disiapkan sari buah terong belanda sebanyak $100 \mathrm{~mL}$ ditambah gula $5 \%$ dan dipasteurisasi pada suhu $80^{\circ} \mathrm{C}$ selama 4,5 menit dan didinginkan pada suhu $37^{\circ} \mathrm{C}$.

Tahap selanjutnya dilakukan penyegaran bakteri yaitu dengan cara mengambil $100 \mu \mathrm{L}$ stok isolat yang disimpan dalam gliserol $30 \%$ pada suhu $-20^{\circ} \mathrm{C}$ dan diinokulasi pada $5 \mathrm{~mL}$ media MRS Broth (MRSB) dan diinkubasi selama 24 jam dengan suhu $37^{\circ} \mathrm{C}$. Setelah inkubasi, media tersebut diamati, hasil positif ditunjukkan dengan kekeruhan pada media, tabung reaksi tersebut kemudian divortex kemudian disentrifugasi pada kecepatan $3500 \mathrm{rpm}$ selama 10 menit. Setelah disentrifugasi, akan terbentuk endapan kultur mikroba pada dasar tabung reaksi. MRSB di atas endapan kultur tersebut dibuang, sedangkan sel yang tertinggal dicuci sebanyak 3 kali. Pencucian sel dilakukan dengan cara menambahkan larutan saline ke dalam tabung reaksi berisi endapan kultur LbF213 lalu divorteks, selanjutnya tabung reaksi disentrifugasi pada kecepatan $3500 \mathrm{rpm}$ selama 10 menit, dan supernatan yang terbentuk setelah proses sentrifugasi dibuang. Pada pencucian terakhir, saline tidak dibuang, tetapi divortex, kemudian diambil $1 \mathrm{~mL}$ dan dipindahkan ke dalam microtube. Kultur dalam microtube disentrifugasi, kemudian cairan di atasnya dibuang hingga tersisa endapan kultur. Diambil $1 \mathrm{~mL}$ dari sari buah yang telah disiapkan dan dimasukkan ke dalam microtube yang di dalamnya terdapat kultur Lactobacillus sp. F213, kemudian di vortex. Selanjutnya campuran kultur Lactobacillus sp. F213 dimasukkan ke dalam $100 \mathrm{~mL}$ sari buah dan dikocok. Sari buah tersebut 
diinkubasi selama 24 jam pada suhu $37^{\circ} \mathrm{C}$ untuk memperoleh starter.

\section{Pembuatan Sari Buah Probiotik Terong Belanda Terfermentasi}

Sari buah yang telah disiapkan sebelumnya dimasukkan sebanyak $70 \mathrm{~mL}$ ke masing-masing botol kaca yang telah disterilisasi. Sukrosa dimasukkan ke dalam sari buah sesuai perlakuan $0 \%, 3 \%, 6 \%, 9 \%$, dan $12 \%$ pada masing-masing botol kaca, kemudian ditambah sari buah ke masingmasing botol kaca hingga mencapai batas garis $90 \mathrm{~mL}$ kemudian diaduk hingga sukrosa terlarut. Sari buah tersebut dipasteurisasi pada suhu $80^{\circ} \mathrm{C}$ selama 4,5 menit kemudian didinginkan hingga suhu $37^{\circ} \mathrm{C}$. Masingmasing produk ditambahkan starter sebanyak $10 \%(10 \mathrm{~mL})$, kemudian difermentasi pada suhu $37^{\circ} \mathrm{C}$ selama 24 jam.

\section{Variabel yang Diamati}

Variabel yang diamati dalam penelitian ini meliputi total BAL dengan metode Total Plate Count (Fardiaz, 1993), total gula dengan metode Anthrone (Apriyantono et al., 1988 dan Andarwulan et al., 2011), total asam dengan metode titrasi netralisasi (Sudarmadji et al.,1996), derajat keasaman dengan pH- meter (AOAC, 1995), uji sensori meliputi pengujian nilai kesukaan terhadap warna, aroma, rasa, dan penerimaan secara keseluruhan, sedangkan uji skor dilakukan terhadap rasa dan warna (Soekarto, 1985).

\section{HASIL DAN PEMBAHASAN}

Hasil analisis pengaruh konsentrasi sukrosa terhadap total bakteri asam laktat (total BAL), total gula, total asam, dan derajat keasaman $(\mathrm{pH})$ dapat dilihat pada Tabel 1.

\section{TOTAL BAL}

Hasil analisis ragam menunjukkan bahwa konsentrasi sukrosa berpengaruh nyata $(\mathrm{p}<0,05)$ terhadap total BAL sari buah probiotik terong belanda terfermentasi. Total BAL terendah ditunjukkan pada perlakuan S0 yaitu 7,61 $\log \mathrm{CFU} / \mathrm{mL}$, sedangkan total BAL tertinggi ditunjukkan pada perlakuan S3 ( konsentrasi sukrosa 9\%) yaitu 9,31 log $\mathrm{CFU} / \mathrm{mL}$. Penambahan sukrosa dari $3 \%$ hingga $9 \%$ menyebabkab peningkatan pertumbuhan bakteri dan kemudian menurun setelah penambahan sukrosa $12 \%$, hal ini disebabkan selama proses fermentasi, bakteri asam laktat memiliki batas optimal penggunaan sukrosa sebagai sumber energi sehingga tidak semua sukrosa yang terdapat dalam produk dapat difermentasi menjadi asam laktat (Sintasari et al.,2014). Pada penelitian yoghurt susu kulit pisang kapok dan kacang hijau, penambahan sukrosa $15 \%$ dapat menghambat pertumbuhan BAL (Dante et al., 2016), hal ini berkaitan dengan hasil penelitian dimana pada konsentrasi sukrosa $12 \%$ total BAL sari buah probiotik terong belanda terfermentasi sudah mengalami penurunan. Konsentrasi sukrosa yang sangat tinggi menyebabkan kondisi lingkungan hipertonik sehingga cairan dalam sel bakteri mengalir keluar yang menyebabkan dehidrasi dan pengkerutan sel mikroorganisme (plasmolysis) (Sutikno et al., 2013).

Sukrosa merupakan sumber energy dan nutrisi yang diperlukan dalam pertumbuhan BAL (Harahap et al., 2018), unsur karbon dalam sukrosa dimanfaatkan oleh BAL untuk menyususn makromolekul seluler dalam proses perkembangbiakannya dan total BAL meningkat. Total BAL meningkat seiring dengan meningkatnya konsentrasi sukrosa hingga titik optimal. Berdasarkan hasil penelitian ini, konsentrasi sukrosa 9\% pada sari buah probiotik terong belanda terfermentasi diduga memberikan kondisi optimal bagi pertumbuhan BAL. 
Tabel 1. Nilai rata-rata total BAL, total gula, dan total padatan terlarut, total asam, derajat keasaman $(\mathrm{pH})$ sari buah probiotik terong belanda terfermentasi

\begin{tabular}{ccccc}
\hline $\begin{array}{c}\text { Konsentrasi } \\
\text { Sukrosa }\end{array}$ & $\begin{array}{c}\text { Total BAL } \\
(\log \text { CFU/ mL) }\end{array}$ & Total Gula $(\%)$ & Total Asam $(\%)$ & $\begin{array}{c}\text { Derajat } \\
\text { Keasaman/pH }\end{array}$ \\
\hline $0 \%(\mathrm{~S} 0)$ & $7,61 \pm 0,98 \mathrm{~b}$ & $7,03 \pm 3,39 \mathrm{c}$ & $1,78 \pm 0,27 \mathrm{a}$ & $4,27 \pm 0,05 \mathrm{c}$ \\
$3 \%(\mathrm{~S} 1)$ & $8,15 \pm 0,22 \mathrm{~b}$ & $10,03 \pm 4,20 \mathrm{~b}$ & $1,64 \pm 0,12 \mathrm{ab}$ & $4,29 \pm 0,02 \mathrm{bc}$ \\
$6 \%(\mathrm{~S} 2)$ & $8,52 \pm 0,11 \mathrm{ab}$ & $12,15 \pm 3,32 \mathrm{~b}$ & $1,71 \pm 0,17 \mathrm{ab}$ & $4,28 \pm 0,03 \mathrm{c}$ \\
$9 \%(\mathrm{~S} 3)$ & $9,31 \pm 0,64 \mathrm{a}$ & $16,98 \pm 1,46 \mathrm{a}$ & $1,53 \pm 0,10 \mathrm{bc}$ & $4,31 \pm 0,03 \mathrm{ab}$ \\
$12 \%(\mathrm{~S} 4)$ & $8,09 \pm 0,19 \mathrm{~b}$ & $17,78 \pm 1,59 \mathrm{a}$ & $1,40 \pm 0,32 \mathrm{c}$ & $4,32 \pm 0,04 \mathrm{a}$ \\
\hline
\end{tabular}

Keterangan: Nilai rata-rata \pm standar deviasi $(n=3)$. Huruf yang sama di belakang nilai rata-rata pada kolom yang sama menunjukkan nilai rata- rata tidak berbeda nyata $(\mathrm{P}>0,05)$

\section{Total Gula}

Berdasarkan hasil analisis ragam menunjukkan bahwa konsentrasi sukrosa berpengaruh sangat nyata $(\mathrm{p}<0,01)$ terhadap total gula sari buah probiotik terong belanda terfermentasi. Nilai rata- rata total gula sari buah probiotik terong belanda mengalami peningkatan sebanding dengan peningkatan konsentrasi sukrosa yaitu berkisar antara $7,03 \%$ hingga $17,78 \%$. Total gula terendah terdapat pada produk S0 sedangkan total gula tertinggi terdapat pada produk S4.

Produk S4 memiliki nilai total gula tertinggi yang tidak berbeda nyata dengan produk S3 karena diduga selama fermentasi bakteri asam laktat memiliki batas optimal pemanfaatan karbon sehingga sukrosa yang ditambahkan tidak dimanfaatkan seluruhnya, selain itu diduga masih terdapat sumber gula sederhana pada buah terong belanda. Gula yang tersisa dihitung sebagai total gula, sehingga semakin tinggi konsentrasi sukrosa pada sari buah probiotik terong belanda terfermentasi, semakin tinggi glukosa dan fruktosa yang terakumulasi dan menyebabkan total gula meningkat (Sintasari et al., 2014).

\section{Total Asam}

Berdasarkan hasil analisis statistik, konsentrasi sukrosa berpengaruh nyata ( $\mathrm{p}<$ $0,05)$ terhadap total asam sari buah probiotik terong belanda terfermentasi. Nilai rata- rata total asam terhitung asam laktat sari buah probiotik terong belanda terfermentasi dapat dilihat pada Tabel 1.

Selama fermentasi bakteri asam laktat yang merupakan bakteri heterofermentatif memecah gula sebagai sumber nutrisi yang menghasilkan produk berupa asam laktat, etanol, asetat, dan $\mathrm{CO}_{2}$ (Sopandi dan Wardah, 2014). Total asam laktat yang dihasilkan berkisar antara 1,40 \% hingga 1,78\%. Berdasarkan analisis statistik, total asam produk $\mathrm{S} 2$ tidak berbeda nyata dengan produk S0, S1, dan S3 namun berbeda nyata dengan produk S4. Perubahan total asam sebanding dengan perubahan total BAL, dimana total BAL pada produk S0, S1, dan S2 tidak berbeda nyata sehingga mengakibatkan total asam yang dihasilkan tidak berbeda nyata pada produk S0, S1, dan S2. Total asam produk S0 berbeda nyata dengan produk S3 dan S4, hal ini diduga pada konsentrasi sukrosa 9\% dan $12 \%$ metabolisme bakteri dalam menghasilkan asam laktat mulai menurun, karena konsentrasi sukrosa yang semakin tinggi, menyebabkan kondisi lingkungan hipertonik sehingga cairan dalam sel bakteri mengalir keluar yang menyebabkan dehidrasi dan pengkerutan sel mikroba sehingga perkembangan bakteri mulai terhambat.

\section{Derajat Keasaman (pH)}

Berdasarkan hasil analisis ragam, konsentrasi sukrosa berpengaruh nyata ( $\mathrm{p}<$ 
$0,05)$ terhadap $\mathrm{pH}$ produk sari buah probiotik terong belanda terfermentasi. Nilai rata- rata $\mathrm{pH}$ sari buah probiotik terong belanda terfermentasi dapat dilihat pada Tabel 1.

Menurut Sopandi dan Wardah, 2014, selama fermentasi bakteri asam lakat yang merupakan bakteri heterofermentatif memecah gula sebagai sumber nutrisi yang menghasilkan produk berupa asam laktat, etanol, asetat, dan $\mathrm{CO}_{2}$. Nilai yang terukur dalam pengukuran $\mathrm{pH}$ adalah konsentrasi ion $\mathrm{H}+$ yang menunjukkan jumlah asam terdisosiasi (Frazier dan Westhoff, 1979).

Produk dengan perlakuan S0 memiliki $\mathrm{pH}$ terendah yaitu 4,27, sementara produk dengan perlakuan $\mathrm{S} 4$ memiliki $\mathrm{pH}$ tertinggi yaitu 4,32. Pada penelitian ini peningkatan $\mathrm{pH}$ sebanding dengan penurunan total asam. Derajat keasaman $(\mathrm{pH})$ produk S0 berbeda tidak nyata dengan produk $\mathrm{S} 1$ dan $\mathrm{S} 2$, sedangkan produk S3 berbeda tidak nyata dengan produk S1 dan S4. Produk S4 berbeda nyata dengan produk S0, S1, S2. Pada produk S4 berbeda nyata dengan ke 3 jenis perlakuan, hal ini diduga pada konsentrasi sukrosa $12 \%$ perkembangan BAL mulai terhambat sehingga asam laktat yang dihasilkan lebih rendah dan menyebabkan peningkatan $\mathrm{pH}$.

\section{Hasil Uji Sensori}

Hasil analisis ragam menunjukkan bahwa konsentrasi sukrosa berpengaruh sangat nyata $(\mathrm{p}<0,01)$ terhadap skor warna, hedonik rasa, skor rasa asam, skor rasa manis, dan hedonik penerimaan keseluruhan sari buah probiotik terong belanda. Sementara konsentrasi sukrosa berpengaruh tidak nyata (p> 0,05) terhadap hedonik warna dan hedonic aroma sari buah probiotik terong belanda. Nilai rata-rata hasil uji sensoris skoring dan hedonik dapat dilihat pada Tabel 2 dan 3 .

\section{Warna}

Hasil analisis ragam menunjukkan bahwa perbedaan konsentrasi sukrosa tidak berpengaruh nyata $(p>0,05)$ terhadap hedonik warna sari buah probiotik terong belanda terfermentasi. Nilai rata- rata uji hedonik terhadap warna sari buah probiotik terong belanda berkisar antara 5,1 hingga 5,5 dengan kriteria agak suka hingga suka. Berdasarkan analisis ragam, konsentrasi sukrosa berpengaruh nyata $(\mathrm{p}<0,05)$ terhadap skor warna produk. Nilai rata- rata skor warna produk berkisar antara 1,8 (jingga) hingga 2,55 (jingga tua). Setelah penambahan sukrosa $3 \%$ nilai rata- rata skor warna produk meningkat yaitu berwarna jingga tua kemudian menurun pada penambahan sukrosa $6 \%$, 9\%, dan $12 \%$ yaitu berwarna jingga. Pada penelitian ini produk S1, S2, S3 tidak berbeda nyata, sedangkan produk S0 dan S4 tidak berbeda nyata, namun pada produk S4 dapat dilihat penurunan skor warna yang berbeda nyata dari produk S1, S2, dan S3.

Terong belanda memiliki zat pewarna alami salah satunya yaitu antosianin. Menurut Sholikin, 2011, Penurunan skor warna dapat dikaitkan dengan peningkatan $\mathrm{pH}$ yaitu pada produk S4 diperoleh skor warna terendah dan nilai $\mathrm{pH}$ tertinggi. Penurunan skor warna diduga karena degradasi warna dari antosianin yang disebabkan oleh kation flavilium yang berwarna merah berubah menjadi basa karbinol.

Antosianin memiliki karakteristik kerangka karbon $\mathrm{C}_{6} \mathrm{C}_{3} \mathrm{C}_{6}$ dengan struktur dasar antosianin adalah 2- fenil- benzofirilium dari garam flavilum (Santoso dan Estiasih, 2014). Pada pH rendah sebagian besar antosianin terdapat dalam bentuk kation flavilium, sedangkan senyawa basa karbinol dan kalkon yang tidak berwarna, jumlahnya kecil (Sari et al., 2005). Peningkatan pH menyebabkan peningkatan jumlah basa karbinol dan kalkon sehingga warna bahan memudar (Rein, 2005). 
Tabel 2. Nilai rata-rata hasil uji sensoris sari buah probiotik terong belanda terfermentasi terhadap warna dan aroma

\begin{tabular}{|c|c|c|c|}
\hline \multirow{2}{*}{$\begin{array}{c}\text { Konsentrasi } \\
\text { Sukrosa }\end{array}$} & \multicolumn{2}{|c|}{ Warna } & \multirow{2}{*}{$\begin{array}{c}\text { Aroma } \\
\text { Hedonik }\end{array}$} \\
\hline & Hedonik & Skor & \\
\hline $0 \%(\mathrm{~S} 0)$ & $5,50 \pm 0,69 \mathrm{a}$ & $1,80 \pm 0,77 \mathrm{~b}$ & $4,80 \pm 1,11 \mathrm{a}$ \\
\hline $3 \%(\mathrm{~S} 1)$ & $5,40 \pm 0,68 \mathrm{a}$ & $2,55 \pm 0,60 \mathrm{a}$ & $5,10 \pm 1,17$ a \\
\hline $6 \%(\mathrm{~S} 2)$ & $5,10 \pm 1,02 \mathrm{a}$ & $2,45 \pm 0,60 \mathrm{a}$ & $5,20 \pm 1,01 \mathrm{a}$ \\
\hline $9 \%(\mathrm{~S} 3)$ & $5,35 \pm 0,99 \mathrm{a}$ & $2,35 \pm 0,67 \mathrm{a}$ & $5,10 \pm 1,02 \mathrm{a}$ \\
\hline $12 \%(\mathrm{~S} 4)$ & $5,20 \pm 1,11 \mathrm{a}$ & $1,95 \pm 0,83 \mathrm{~b}$ & $4,95 \pm 0,89 \mathrm{a}$ \\
\hline
\end{tabular}

Keterangan: Nilai rata-rata \pm standar deviasi $(n=3)$. Huruf yang sama di belakang nilai rata-rata pada kolom yang sama menunjukkan perlakuan berbeda tidak nyata ( $>>0,05)$. Kriteria hedonik : 1 = sangat tidak suka, $2=$ tidak suka, $3=$ agak tidak suka, $4=$ biasa, $5=$ agak suka, $6=$ suka, 7 = sangat suka. Kriteria skor warna : 1= jingga muda, $2=$ jingga, $3=$ jingga tua.

Tabel 3. Nilai rata-rata hasil uji sensoris sari buah probiotik terong belanda terfermentasi terhadap rasa asam, rasa manis, dan penerimaan keseluruhan.

\begin{tabular}{ccccc}
\hline Konsentrasi & \multicolumn{3}{c}{ Rasa } & Penerimaan keseluruhan \\
\cline { 2 - 5 } Sukrosa & Hedonik & Skor Asam & Skor Manis & Hedonik \\
\hline $0 \%$ (S0) & $3,20 \pm 1,32 \mathrm{c}$ & $3,45 \pm 0,76 \mathrm{a}$ & $1,15 \pm 0,49 \mathrm{~d}$ & $3,65 \pm 1,39 \mathrm{c}$ \\
$3 \%$ (S1) & $4,45 \pm 1,32 \mathrm{~b}$ & $2,80 \pm 0,70 \mathrm{~b}$ & $1,80 \pm 0,52 \mathrm{c}$ & $4,60 \pm 0,99 \mathrm{~b}$ \\
$6 \%(\mathrm{~S} 2)$ & $4,35 \pm 1,53 \mathrm{~b}$ & $2,90 \pm 0,55 \mathrm{~b}$ & $1,85 \pm 0,67 \mathrm{c}$ & $4,55 \pm 1,19 \mathrm{~b}$ \\
$9 \%(\mathrm{~S} 3)$ & $5,45 \pm 1,10 \mathrm{a}$ & $2,30 \pm 0,66 \mathrm{c}$ & $2,60 \pm 0,60 \mathrm{~b}$ & $5,35 \pm 0,99 \mathrm{a}$ \\
$12 \%(\mathrm{~S} 4)$ & $5,90 \pm 0,64 \mathrm{a}$ & $1,65 \pm 0,59 \mathrm{~d}$ & $3,35 \pm 0,59 \mathrm{a}$ & $5,50 \pm 0,69 \mathrm{a}$ \\
\hline
\end{tabular}

Keterangan: Nilai rata-rata \pm standar deviasi $(n=3)$ Huruf yang sama di belakang nilai rata-rata pada kolom yang sama menunjukkan perlakuan berbeda tidak nyata $(\mathrm{p}>0,05)$. Kriteria hedonik : 1 = sangat tidak suka, $2=$ tidak suka, $3=$ agak tidak suka, $4=$ biasa, $5=$ agak suka, $6=$ suka, $7=$ sangat suka. Kriteria skor rasa asam $: 1=$ tidak asam, $2=$ agak asam, $3=$ asam, $4=$ sangat asam. Kriteria skor rasa manis : $1=$ tidak manis, $2=$ agak manis, 3 = manis, 4 = sangat manis.

\section{Aroma}

Hasil analisis ragam menunjukkan bahwa konsentrasi sukrosa berpengaruh tidak nyata $(\mathrm{p}>0,05)$ terhadap hasil uji hedonik aroma sari buah probiotik terong belanda. Nilai rata- rata hedonik aroma sari buah probiotik terong belanda berkisar antara 4,80 hingga 5,20 dengan kriteria agak suka. Penambahan sukrosa tidak memberikan banyak pengaruh pada aroma karena gula tidak memiliki aroma yang menonjol dan kuat (Asmawati et al.,2018).

\section{Rasa}

Hasil analisis ragam menunjukkan bahwa konsentrasi sukrosa berpengaruh sangat nyata $(\mathrm{p}<0,01)$ terhadap tingkat kesukaan (hedonik) rasa, skor rasa asam, skor rasa manis sari buah probiotik terong belanda. Nilai rata-rata uji hedonik produk berkisar antara 3,2 hingga 5,9 dengan kriteria agak tidak suka hingga suka. Nilai rata- rata skor rasa asam berkisar antara 1,6 hingga 3,45 dengan kriteria agak asam hingga asam, nilai rata- rata skor rasa manis berkisar antara 1,15 hingga 3,35 dengan kriteria tidak manis hingga manis. Semakin 
tinggi konsentrasi sukrosa rasa manis produk meningkat. Penilaian panelis terhadap rasa secara hedonik meningkat seiring dengan konsentrasi sukrosa. Produk dengan konsentrasi sukrosa $12 \%$ (S4) mendapat nilai tertinggi pada uji hedonik yaitu dengan rasa agak asam dan manis, produk S4 tidak berbeda nyata dengan produk S3 dengan konsentrasi sukrosa 9\% yang memiliki rasa agak asam dan manis. Produk yang disukai panelis adalah produk dengan rasa agak asam, dan manis. Rasa manis diperoleh dari kandungan gula yang lebih tinggi pada produk S4 dan S3 karena tidak diproses seluruhnya selama fermentasi.

\section{Penerimaan Keseluruhan}

Hasil analisis ragam menunjukkan bahwa konsentrasi sukrosa berpengaruh sangat nyata $(\mathrm{p}<0,01)$ terhadap uji hedonik penerimaan keseluruhan sari buah probiotik terong belanda. Nilai rata- rata uji hedonik penerimaan keseluruhan sari buah probiotik terong belanda berkisar antara 3,65 hingga 5,5 dengan kriteria biasa hingga suka. Dari penilaian panelis terhadap penerimaan keseluruhan sari buah probiotik terong belanda, diperoleh hasil yaitu produk dengan perlakuan S4 mendapat nilai tertinggi dari seluruh perlakuan yaitu dengan kriteria disukai, produk S4 tidak berbeda nyata dengan produk S3 dengan kriteria agak disukai oleh panelis.

\section{KESIMPULAN DAN SARAN Kesimpulan}

Berdasarkan hasil dan pembahasan penelitian maka dapat disimpulkan sebagai berikut.

1. Perbedaan konsentrasi sukrosa berpengaruh terhadap total BAL, total gula, total asam, $\mathrm{pH}$, skor warna, hedonik rasa, skor rasa asam, skor rasa manis, dan hedonik penerimaan keseluruhan, namun tidak berpengaruh terhadap hedonik warna dan hedonik aroma sari buah probiotik terong belanda terfermentasi.

2. Perlakuan sukrosa dengan konsentrasi 9\% menghasilkan sari buah probiotik terong belanda terfermentasi dengan karakteristik terbaik yaitu total BAL 9,31 log CFU/ mL, total gula $16,98 \%$, total asam 1,53\%, $\mathrm{pH} 4,31$. Sifat sensori yang diperoleh yaitu warna jingga yang agak disukai, aroma agak disukai, rasa agak asam dan manis yang agak disukai, dan penerimaan keseluruhan yang agak disukai.

\section{Saran}

Berdasarkan hasil penelitian, disarankan untuk menambahkan sukrosa dengan konsentrasi $9 \%$ sehingga menghasilkan sari buah probiotik terong belanda terfermentasi dengan karakteristik terbaik. Perlu dilakukan penelitian lebih lanjut untuk mengetahui umur simpan sari buah probiotik terong belanda terfermentasi.

\section{DAFTAR PUSTAKA}

Andarwulan, N., F. Kusnandar, dan D. Herawati. 2011. Analisis Pangan. Dian Rakyat, Jakarta.

Anonimous. 2014. Minuman Susu Fermentasi Berperisa. SNI 7552: 2009. Badan Standardisasi Nasional. Jakarta.

AOAC, 1995. Official Methods of Analysis of AOAC International. AOAC Intl, Washington DC.

Apriyantono, A., D. Fardiaz, N.L. Puspitasari, Sedarnawati, dan S. Budiyanto. $1988 . \quad$ Petunjuk Laboratorium Analisis Pangan. IPB Press : Bogor.

Asmawati, H. Sunardi, S. Ihrom. 2018. Kajian persentase penambahan gula terhadap komponen mutu sirup buah 
naga merah. Jurnal Agrotek. 5(2) : 97- 105 .

Athar, N., et al. 2003. The Concise New Zealand Food Composition Tables. New Zealand Institute for Crop \& Food Research Limited/Ministry of Health. Palmerston North, New Zealand.

Atviolani,R., S. Effendi, E.T. Sutrisno. 2016. Pengaruh Konsentrasi Sukrosa dan Pektin TerhadapKarakteristik Marmalade Buah Naga Merah (Hylocereus Polyrhizus). Skripsi. Tidak dipublikasikan. Universitas Pasundan, Bandung

Dante, L. J., I.K. Suter, L.P.T. Darmayanti. 2016. Pengaruh konsentrasi sukrosa terhadap karakteristik yoghurt dari susu kulit pisang kepok (Musa paradisiaca formatypica) dan kacang hijau (Phaseolus radiatus l.). Jurnal Ilmu dan Teknologi Pangan. $5(2)$ : 74- 84.

Diniyah, N., A. Subagio dan M. Fauzi., 2013. Produksi minuman fungsional sirsak (Anona muricata. Linn) dengan fermentasi bakteri asam laktat. Jurnal Teknotan. 2(7):10071012.

Ding, W.K. dan N.P. Shah. 2008. Survival of free and microencapsulated probiotic bacteria in orange and apple juices. International Food Journal. 15(2): 219-232.

Djufry, F., J. Limbongan, N.Lade, dan B.Saranga. 2016. Karakterisasi tanaman tamarillo di Sulawesi Selatan. Bul. Plasama Nutfah. 22(2): 127-136.

Fardiaz. 1993. Analisis Mikrobiologi Pangan Edisi Pertama.Raja Grafindo Persada, Jakarta.
Frazier dan Westhoff 1978. Food Mikrobiologi 3rd Ed. Tata Mc Graw Hill Publishing Company Ltd, New York.

Garcia, J.M., L.J.Prieto, A.Guevara, D. Malagon, C. Osorio. 2016. Chemical Studies of Yellow Tamarillo (Solanum betaceum Cav.) Fruit Flavor by Using a Molecular Sensory Approach. 21 (12) : 1- 11.

Gomez, K.A., dan A.A. Gomez 1995. Prosedur Statistik untuk Penelitian Pertanian. Edisi kedua. UI- Press, Jakarta.

Harahap, N.O., V.S. Johan, dan U. Pato. 2018. Pembuatan minuman fermentasi sari tomat dengan menggunakan Lactobacillus casei subsp. casei R-68. JOM UR 5(2):115.

Membre, J. M., M. Kubaczka dan C. Chene. 1999. Combined effects of $\mathrm{pH}$ and sugar on growth rate of Zygosaccharomyces rouxii, a bakery product spoilage yeast. App. Env. Microbiol. 65(11):4921- 4925.

Mousavi, Z.E., S.M. Mousavi, S.H. Razavi, Z.E. Djomeh, H. Kiani. 2010. Fermentation of pomegranate juice by probiotic lactic acid bacteria. World Journal of Microbiology and Biotechnology. 27 (1) : 123- 128.

Nurainy,F., S.Rizal, Suharyono, dan E. Umami. 2018. Karakteristik minuman probiotik jambu biji (Psidium guajava) pada berbagai variasi penambahan sukrosa dan susu skim. Jurnal Aplikasi Teknologi Pangan. 7(2): 47-54

Rein, M. 2005. Copigmentation Reaction and Color Stability of Berry Anthocyanin. Disertasi. Tidak 
dipublikasikan. Universitas of Helsinki.

Rini, A.P. 2019. Viabilitas Lactobacillus sp. F213 pada Berbagai Minuman Sari Buah Probiotik Selama Penyimpanan. Unpublished.

Purwoko, T. 2007. Fisiologi Mikroba. Jakarta : Bumi Aksara.

Santoso,W.E. A., dan T. Estiasih. 2014. Kopigmentasi ubi jalar ungu (ipomea batatas var. ayamurasaki) dengan kopigmen na-kaseinat dan protein whey serta stabilitasnya terhadap pemanasan. Jurnal Pangan dan Agroindustri 2(4) : 121- 127.

Sari, P., F. Agustina, M. Komar., Unus., M. Fauzi., T. Lindriati. 2005. Ekstraksi dan Stabilitas Antosianin dari Kulit Buah Duwet. Jurnal Teknol dan Industri Pangan. 16 (2) : 142- 150.

Seelam, N.S. H. Akula, dan U. Katika, V.S.R. Obulam. 2017. Production, characterization and optimization of fermented tomato and carrot juices by using Lysinibacillus sphaericus isolate. Journal of Applied Biology and Biotechnology. 5(04) : 66- 75.

Sholikhin, J., B. Luktiati, Balqis. 2013. Analisis dan Uji Stabilitas Ekstrak Mahkota Bunga Dadap Merah (Eritrina crista-galli L.). Skripsi. Tidak dipublikasikan. Universitas Negeri Malang, Malang.

Simanjuntak M, T. Karo, dan S. Ginting. 2017. Pengaruh penambahan gula pasir dan lama fermentasi terhadap mutu minuman ferbeet (fermented beetroot).Jurnal rekayasa pangan dan pertanian Vol. 6 (1) : 96- 101.

Sintasari, R.A., J. Kusnadi, dan D.W. Ningtyas. 2014. Pengaruh penambahan konsentrasi susu skim dan sukrosa terhadap karakterisik minuman probiotik sari beras merah. Jurnal Pangan dan Agroindustri. 2 (3) : 65- 75 .

Soekarto, S.T. $1985 . \quad$ Penelitian Organoleptik Untuk Industri Pangan dan Hasil Pertanian. Bharata Karya Aksara, Jakarta.

Sopandi,T. dan Wardah, 2014. Mikrobiologi Pangan, Teori dan Praktetk. Andi Offset, Yogyakarta.

Sudarmadji, S. B. Haryono, dan Suhardi. 1996. Analisa Bahan Makanan dan Pertanian. Liberty Yogyakarta. Yogyakarta.

Sujaya, I N., D.M. Sukrama, Y. Ramona, K.A. Nocianitri, T. Sone, dan K. Asano. 2012. Resistantce of Lactobacillus sp. F213 in human gastrointestinal tract as reveal by Polymerase Chain ReactionDenaturing Gradient Gel Electrophoresis of fecal microbiome. (Laporan Penelitian Kerjasama Luar Negeri, Universitas Udayana).

Suryani, Y., A. B. Oktavia dan S. Umniyati. 2010. Isolasi dan karakterisasi bakteri asam laktat dari limbah kotoran ayam sebagai agensi probiotik dan enzim kolesterol reduktase. Biologi dan Pengembangan Profesi Pendidik Biologi. Biota. 12 (3): 177-185.

Sutikno, S. Rizal, dan Marniza. 2013. Effects of sugar type and concentration on the characteristics of fermented turi (Sesbania grandiflora (L.) Poir) milk. Journal Food Agric. 25 (8) : 576-584

WHO/FAO. 2001. Joint FAO/ WHO Expert Consultation on Evaluation of Health and Nutritional Properties of 
Probiotics in Food Including Powder Milk with Live Lactic Acid Bacteria. American Cordoba Park Hotel, Cordoba, Argentina.

Yunus,Y. dan E. Zubaidah. 2015. Pengaruh konsentrasi sukrosa dan lama fermentasi terhadap viabilitas 1 . casei selama penyimpanan beku velva pisang ambon. Jurnal Pangan dan Industri. 3 (2): 303-312. 